\title{
O ICMS ECOLÓGICO E A IMPLEMENTAÇÃO DE POLÍTICAS PÚBLICAS AMBIENTAIS NO ESTADO DE RONDÔNIA
}

\section{THE ECOLOGICAL ICMS AND THE IMPLEMENTATION OF PUBLIC ENVIRONMENTAL POLITICS IN THE STATE OF RONDÔNIA}

\author{
Thiago Vieira Mathias de Oliveira ${ }^{1}$ \\ Yully Cristiano Murer ${ }^{2}$
}

\begin{abstract}
RESUMO: A defesa do meio ambiente é um princípio da ordem econômica brasileira, e o meio ambiente ecologicamente equilibrado é um direito fundamental reconhecido pela Organização das Nações Unidas (ONU) e contemplado pela Constituição Federal de 1988, em seu Art. 225. Para assegurar esse direito, O Estado deve, juntamente com a sociedade, implementar políticas públicas que promovam o desenvolvimento econômico de forma sustentável. Nesse sentido, pode-se lançar mão de instrumento de políticas públicas econômico-ambientais, tais como o ICMS Ecológico. Trata-se de um critério ecológico de definição da forma de participação de Municípios na receita do ICMS de seus respectivos Estados, agindo como meio de compensação fiscal a Municípios que não podem explorar economicamente áreas que constituem unidades de conservação e outras áreas protegidas existentes em seus territórios, bem como incentivo para a criação de novas áreas de proteção ambiental. O presente estudo tece algumas considerações sobre a legislação e impactos do ICMS Ecológico no Estado de Rondônia.
\end{abstract}

Palavras-chave: Meio Ambiente; Políticas Públicas; ICMS Ecológico; Rondônia.

\begin{abstract}
The environmental protection is a principle of Brazilian economic policy, and ecologically balanced environment is fundamental rights recognized by the United Nations (UN) and contemplated by the 1988 Federal Constitution, in its Article 225.To ensure this right; the State together with society shall implement public politics that promote economic development in a sustainable manner. In this sense, one way is to use a public instrument of economic and environmental benefits, such as the Ecological ICMS. This is one ecological criterion for defining the form of participation by the municipals in the ICMS revenue from their respective states. This politic can act as a tax relief to municipals that can not economically explore conservation and other protected areas in their territories, as well as incentives for the creation of new protected areas. This paper presents some considerations about the legislation and impacts of the Ecological ICMS in the state of Rondônia.
\end{abstract}

Key-words: Environment; Public Politics; Ecological ICMS; Rondônia.

\footnotetext{
${ }^{1}$ Graduado em Direito pela Universidade Estadual de Londrina (2006), Mestre em Direito pela Universidade Estadual de Londrina (2009). Professor de Direito Constitucional e Coordenador de Pesquisa e Monografia Jurídica da Graduação em Direito do Centro Universitário Luterano de Ji-Paraná (CEULJI/ULBRA)...

${ }^{2}$ Graduado em Direito pelo Centro Universitário Luterano de Ji-Paraná (CEULJI/ULBRA) (2009). Agente Administrativo da Superintendência da Zona Franca de Manaus.
} 


\section{INTRODUÇÃO}

O meio ambiente constitui-se cenário e matéria-prima para a evolução da humanidade. É neste meio que o ser humano se localiza fisicamente e com os recursos por ele fornecidos torna-se possível não apenas a fundamental manutenção da vida, mas também o desenvolvimento da produção e da tecnologia.

No entanto, exatamente em função do desenvolvimento que ajuda a constituir, o meio ambiente vem sendo cotidianamente alvo de inúmeros abusos.

O Direito vem adquirir uma grande importância, neste contexto, na medida em que reconhece o meio ambiente equilibrado como direito fundamental e que determina as ações do Estado com relação à questão ecológica. Elemento central na relação entre o Direito e o meio ambiente é, portanto, a determinação dos mecanismos potencialmente úteis para a harmonização da estrutura econômica presente à necessidade de preservação ambiental, o que se dá por meio da interferência estatal. Dentre tais mecanismos, este estudo abordará as políticas públicas econômico-ambientais que lançam mão da tributação para realização desse propósito.

A cobrança de tributos tem como principal objetivo o financiamento das ações do Estado, as quais devem obrigatoriamente ter em conta a preservação ecológica. Por outro lado, os instrumentos fiscais são relevantes para direcionar as atividades públicas e privadas, podendo, de amplo modo, influenciar a utilização de critérios ambientais diante dos tradicionais mecanismos de produção de desenvolvimento.

Quando o Direito Tributário se preocupa com a questão ecológica estuda como a estrutura da norma jurídica tributária pode ser útil para a preservação dos recursos naturais. Quando o Direito Financeiro tem esta preocupação, se atém aos mecanismos que influenciam a obtenção de receitas e o destino de despesas tributárias no contexto da realização de políticas públicas ambientais. Ainda que não se ignore o aspecto técnico-fiscal primeiramente ressaltado, não ocupa ele posição central neste estudo, cujo principal propósito volta-se para a segunda perspectiva.

Uma vez definidos os fundamentos para a utilização dos instrumentos econômicos e tributários na consecução das políticas públicas ambientais, o estudo dedicará atenção à exposição da experiência do ICMS Ecológico, mecanismo brasileiro de redistribuição de valores obtidos com a instituição do Imposto Sobre Circulação de Mercadorias e Serviços de Transporte Intermunicipal e Interestadual e de Comunicações - ICMS adotado em vários Estados, por meio do qual a tributação vem sendo um instrumento capaz de tornar possível a construção de um novo modelo de desenvolvimento sustentável. 
Culmina-se em fim, com a exposição dos aspectos jurídicos da implantação do ICMS Ecológico no Estado de Rondônia, para seguir com a análise dos impactos fiscais e ambientais que ele causou naquele Estado.

\section{A FUNÇÃO DAS POLÍTICAS PÚBLICAS PARA PROTEÇÃO DO MEIO AMBIENTE EM UMA ECONOMIA DE MERCADO}

Porque o Estado brasileiro adotou o modo de produção capitalista, teve de lançar mãos de uma tutela jurídica das condições para que o sistema econômico continuasse operando. Para a Economia, a manutenção dessas estruturas se verte no conceito de crescimento econômico, sinônimo de ótimo desenvolvimento da produção, principalmente mediante as inovações tecnológicas, do consumo - que impulsiona a produção -, do investimento em produção futura mediante emprego do lucro como capital para reprodução, do lucro em si, que convence o setor produtivo a (re)investir na produção. "Toda teoria keynesiana de bem-estar assenta-se sobre a produção e consumo. Aquela como motivadora e regulamentadora deste, e este como fomentador daquela. Constrói-se um ciclo de interdependência com o objetivo de provocar-se um constante aumento da produção" (DERANI, 2001, p. 99). Em linhas gerais, o crescimento econômico tem por fim o aumento da capacidade produtiva da economia, da produção de bens e serviços de um determinado país ou setor (PIB).

Além do lucro, para que haja investimento na produção é preciso se apresentar os fatores necessários ou as condições materiais ao investimento, notadamente crédito (liquidez, dinheiro), trabalho e meios de produção, que são resultado de trabalhos pretéritos, e material para produção, categoria esta na qual se destaca os recursos:

\footnotetext{
O meio ambiente, e também a sociedade, são entidades "naturais", no sentido de que independem do propósito humano, o primeiro tendo uma existência autônoma que precede ao aparecimento da segunda. Assim o sistema econômico, que é uma ferramenta da sociedade, não passa de um subsistema aberto do ecossistema, precisando dele vitalmente como fonte supridora de recursos e como espaço onde faz o lançamento dos dejetos resultantes das atividades produtivas e de consumo. (CAVALCANTI, 1996, p. 319).
}

Portanto, o crescimento econômico é conseqüência do aumento do uso da matéria-prima natureza. $\mathrm{O}$ fator natureza integra necessariamente o movimento econômico, sem que, contudo, esse fator seja necessariamente quantificado monetariamente. Este processo consiste 
na apropriação dos bens da natureza, ou seja, de bens do tipo públicos ou livres à medida que não recebem no mercado sua devida tradução em valores monetários. São bens cujo uso não implica custos e para os quais não se atribui preços e mesmo assim são inseridos no processo produtivo à medida que, em alguns casos, sua natureza renovável tem facilitado sua exploração.

A lógica da produção capitalista é única e exclusivamente a manutenção de seu próprio sistema e por isso o objetivo final é o lucro, que garante o predomínio do mercado financeiro sobre o mercado de bens ${ }^{3}$. Os bens que são colocados à disposição pela natureza são tratados como bens produzíveis, mas, a princípio, passíveis de utilização. E os efeitos de que disto decorrem podem ser reduzidos, em termos econômicos, a um problema de alocação.

\begin{abstract}
Uma das razões que explicam a negligência quanto aos temas ambientais nas teorias sobre o desenvolvimento econômico reside na forma como se entendia o processo do crescimento. O enfoque neoclássico centra-se no problema da taxa ótima de acumulação de capital, já que supõe que o crescimento se originava na alocação dos fatores e do processo tecnológico. Os recursos naturais participam como mais um insumo reproduzível. Também se admite serem os recursos naturais disponíveis em quantidades ilimitadas, não se constituindo em efetiva restrição ao aumento da produção (GUERRA; SUAREZ, 1997, p. 87).
\end{abstract}

Com isso subestima-se ou ignora-se o valor econômico total já que os bens livres se tornam ineficientes ou abundantemente explorados. Há uma dialética facilmente perceptível entre finitude de recursos naturais e pretensão de crescimento infinito da produção. As definições mais difundidas de ciência econômica, que não levam em conta diretamente esta questão, traçam como seu objeto o estudo da utilização de recursos escassos para a satisfação de necessidades humanas ilimitadas. Porém, o problema dos limites deve ser considerado um problema de velocidade de utilização, interessando na realidade não a finitude absoluta dos recursos naturais, que é um problema secundário, mas se a sociedade humana poderá substituí-los antes que se acabem ou se os empregarão de forma que estarão esgotados antes que a espécie humana (FOLADORI, 2001, p. 120).

A própria ciência econômica verificou que se fazia necessário considerar o fator natureza entre os elementos da cadeia do modo capitalista de produção de forma que ela deixasse de ser utilizada como um bem livre e fazendo com que o recurso natural obtivesse um valor

\footnotetext{
${ }^{3}$ A construção clássica do modo de produção capitalista tem uma concepção economicista da natureza que é vista como simples recurso para produção de bens, não considerando as demais dimensões da realidade e enfocando somente a produção e a produtividade econômica. No plano prático, implica a concepção de política de desenvolvimento embasada apenas no crescimento da economia, não levando em conta os aspectos sociais e ambientais, ou o que se chama de fetichização da taxa de crescimento que toma esse índice como equivalente à melhoria das condições de vida da sociedade, mesmo que para isso se degrade o meio ambiente.
} 
monetário, para assim, receber um tratamento mais comedido. Isso porque, se as fontes naturais de energia renováveis forem usadas racionalmente, é possível recuperar periodicamente alguma parte, o que significa que as restrições ao seu uso poderão ser abrandadas. Quanto às fontes naturais de energia não-renováveis, que exigem em quantidade limitada e não têm condições de regeneração, se não substituídas no futuro por outras fontes renováveis, estabelecerão um limite ao crescimento econômico.

A escola econômica neoclássica e também a keynesiana consideram a economia a alocação de recursos escassos e o mercado como mecanismo para essa alocação pela sua "mão invisível". Porém esse é um pressuposto restrito aos bens e serviços que com seus preços se intercambiam no mercado, ficando fora da análise econômica as bases materiais sobre as quais a produção se sustenta, ou seja, os recursos naturais e os resíduos da produção, ou seja, a depredação e a poluição. Para o devido planejamento das atividades produtivas, se fez necessário a avaliação da divergência entre os seus custos privados, embutidos no combustível, na matéria prima, na operação, etc., custos estes arcados individualmente por cada agente econômico e os custos sociais, da sociedade como um todo e que não são arcados individualmente e proporcionalmente por cada agente econômico pelas condições de laissez-faire.

Esta postura reflete a necessidade de manutenção das bases vitais da produção e reprodução do próprio homem, para além da manutenção de modos produtivos, isto é, da preservação do ambiente como manutenção da capacidade econômica de um setor ou Estado. A economia está sujeita a restrições físicas já que é um sistema circular e aberto, funcionando como suporte do sistema ecológico. Para a Economia, externalidades surgem quando o consumo ou a produção de um bem gera efeitos adversos ou benéficos a outros consumidores e/ou empresas, e estes não são compensados ou não são obrigados compensar efetivamente no mercado via o sistema de preços. Haverá externalidades sempre que uma determinada relação econômica produz efeitos geralmente não mensuráveis a sujeitos que não participam daquela determinada relação.

Isso acontece, por exemplo, com a instalação de uma usina hidrelétrica, que trará desenvolvimento regional, como a geração de empregos, a valorização do comércio, regularização da vazão do rio, efeitos enquadrados como externalidades positivas. Todavia, ocorrerão problemas ambientais como a perda das espécies de animais e vegetais, dos peixes e da mata ciliar, a proliferação de mosquitos, o que configura externalidades negativas.

O significado da expressão externalidades em seu sentido negativo tende a aumentar à medida que as economias se desenvolvem e as condições do ambiente para recebê-los e assi- 
milá-los diminuem, incrementando assim o valor dos recursos naturais (GUERRA; SUAREZ, 1997, p. 86). Com isso estabelecem-se limites à livre utilização ou apropriação dos recursos naturais à medida que os recursos de mais alto grau, explorados primeiro, chegam a ser esgotado e têm que ser substituídos por recursos de menor grau5.

O problema específico da poluição retrata um caso típic ${ }^{4}$ de externalidade negativa que pode ser também denominada de custo externo ou ainda deseconomia externa. Luciana Togeiro de Almeida (1998, p. 27-28) explica que para que ocorra uma externalidade negativa, duas condições devem ser observadas: "1) a atividade de um agente (poluidor) causa uma perda de bem-estar para o outro; 2) esta perda de bem-estar não é compensada (a vítima não recebe uma quantia em valor equivalente aos danos sofridos)."

Percebe-se que a externalidade imposta a outrem ocorre por meio da violação de um bem sem proprietário, ou melhor, um bem de domínio universal, o meio-ambiente. Numa economia de livre mercado, como nenhum agente específico pode exigir a titularidade de direitos sobre o meio ambiente, este se apresenta como um bem sem preço:

O enfoque típico de política ambiental sugerido pela teoria econômica (mainstream) tem sido buscar meios para "internalizar" as externalidades no processo de decisão dos agentes poluidores. Ou seja, uma vez reconhecida a falha do mercado, para evitar a degradação ambiental, a discussão relevante é escolher o meio mais eficiente economicamente (custo mínimo) para que os agentes poluidores considerem os custos sociais de degradação nos seus cálculos privados de custo benefício e, com isso, corrija a sua ação (ALMEIDA, 1998, p. 37).

Não há motivação econômica para a compensação voluntária por parte do poluidor. Por isso a intervenção governamental se apresenta como necessária, quando se trata de externalidades negativas ao meio-ambiente, vez que o setor privado não tem interesse econômico para estabilizar a situação. Para tanto, a forma com que o Estado intervirá, por meio de políticas públicas ambientais. As políticas públicas consistem em instrumentos estatais de intervenção na economia e na vida privada, consoante limitações e imposições previstas na própria Constituição, visando a assegurar as medidas necessárias para a consecução de seus objetivos, o que demanda uma combinação de vontade política e conhecimento técnico. (APPIO, 2005. p. 143 -144). Os instrumentos utilizados pelo governo para intervir na sociedade, na economia, na política, em busca de melhores condições de vida aos seus cidadãos são as políticas públicas.

\footnotetext{
${ }^{4}$ Já no século XVIII, Stuart Mill acreditava que o processo do crescimento econômico terminaria no "estado estacionário". Nesse ponto haveria um nível estático de população servida por uma quantidade fixa de infra-estrutura.
} 
Na visão de Fernando G. Tenório (2002, p.2), política pública é uma ação deliberada dos poderes públicos constituídos que objetiva atender às necessidades de uma sociedade. Essas ações podem ser definidas para atender demandas focalizadas, que dão atenção a problemas que afetam parte de uma dada população, ou demandas universalistas, que dão atenção a problemas que afetam a população no seu todo. Tais ações também contribuem à solução de questões setoriais, como educação, habitação, estrutura agrária, saúde, saneamento, segurança, transporte, meio ambiente e assim por diante, ou de questões geograficamente delimitadas nacional, regional, sub-regional ou localmente.

A preservação e proteção de equilíbrio ao meio ambiente é uma imposição constitucional a todos os administradores públicos, independentemente da esfera de poder a que pertençam6. O Estado é o primeiro obrigado a garantir esse direito aos cidadãos. É inequívoco, pois, que a preservação e proteção do equilíbrio do meio ambiente são de ordem imperativa. É primordial que o meio ambiente seja alçado à condição que merece ter, pois a sua proteção coincide com a do próprio ser humano.

A ordem econômica estabelecida pela Constituição Federal de 1988 (CF/88) é expressão para a construção do Estado Democrático de Direito, segundo seu Art. $1^{\circ}$, indicando a legitimidade popular para exigir do Estado políticas públicas para a proteção ambiental. Isso porque a defesa do meio ambiente é princípio impositivo, justificando a reivindicação de qualquer interessado para a realização de políticas públicas nessa direção.

Cumpre ao gestor público a implementação de políticas públicas que garantam o pleno gozo por todos os membros da coletividade da totalidade dos direitos estabelecidos constitucionalmente, notadamente do rol de direitos fundamentais. O debate sobre a escolha de instrumentos mais adequados a esse propósito no âmbito ambiental remete à opção de mecanismos de:

a) regulação direta do comportamento do poluidor por autoridades governamentais, por meio do exercício do poder de polícia, do zoneamento ambiental, do licenciamento ambiental e do estudo de impacto ambiental (EIA/RIMA).

b) incentivos econômicos para induzir o poluidor e as autoridades competentes a tomar iniciativa de reduzir os níveis de poluição, como:

1. concessão de incentivos fiscais às empresas que investem em meio ambiente;

2. a concessão de redução de alíquotas ou isenções às atividades e aos produtos menos poluidores (seletividade ambiental);

3. tributação da propriedade com base em critérios ambientais;

4. repasse de verbas aos Municípios que preservam o ecossistema; 
Esses são alguns meios disponíveis para o Estado implementar políticas públicas ambientais com fito de combater as externalidades do mercado.

\section{A FUNÇÃO DOS INCENTIVOS FISCAIS NA IMPLEMENTAÇÃO DE POLÍTICAS PÚBLICAS AMBIENTAIS E A FUNÇÃO EXTRAFISCAL DO ICMS ECOLÓGICO}

Quando se coloca em pauta a discussão acerca proteção do meio ambiente por meio de instrumentos tributários, a questão que apresenta maior polêmica é se a proteção do meio ambiente deveria se realizar por meio da instituição de tributos ou se deveria ocorrer por meio de incentivos fiscais.

A instituição de tributos ambientais ou “ecotributos" visa à internalização compulsória dos custos ambientais impedindo que um determinado agente econômico poluidor imponha, unilateralmente, a toda a sociedade, o ônus de suportar tal deseconomia. Nesse contexto, que o agente econômico somente irá participar para conservação do meio ambiente à medida que os custos para evitar o dano ambiental - revertidos no pagamento de tributos - fiquem abaixo do custo de reparação do dano, geralmente traduzido na forma de sanções cíveis, penais e administrativas. Acima deste limite perde-se o interesse por uma redução da poluição, o que demonstra o efeito negativo do ecotributo. Não optando pela via tributária para internalização compulsória dos custos ambientais, possibilita-se que o produto seja colocado no mercado a um preço mais reduzido, subvencionado pelo conjunto da sociedade que suportará as externalidades negativas não consideradas.

Se a opção for feita pela internalização dos custos ambientais por meio da imposição de tributos, haverá necessariamente um aumento no preço da mercadoria, diminuindo-se a quantidade de sujeitos que têm acesso a ela. Por causa do aumento do custo para aquisição ou manejo dos recursos naturais surge uma nova forma de exclusão da concorrência do mercado. A instituição de tributos ambientais apresenta o efeito indesejado de monetarização do direito ambiental.

Ao se utilizar tributo com efeito indutor, o contribuinte não é mais visto como alguém que gera danos, mas como alguém que "paga a conta" e, portanto, está autorizado a consumir ou usar bens de natureza ambiental. A conseqüência, a médio prazo, é a redução de sua propensão a evitar práticas danosas ao ambiente, além da própria perda da consciência ambiental. Nesta direção, e visando a promover a proteção do meio ambiente, o Estado pode lançar mão de ações negativas, utilizando técnicas de desestímulo por meio das quais busca influenciar o comporta- 
mento indesejado, obstaculizando-o ou atribuindo-lhe conseqüências desagradáveis, como é o caso da majoração de tributos ou a instituição de novas exações.

Por outro lado, o Poder Público pode optar por ações afirmativas diante da técnica de incentivos que buscam influenciar o comportamento desejado, facilitando-o ou atribuindo-lhe conseqüências agradáveis. Essa técnica pode ocorrer pela sanção positiva ou premial que assegura a quem realiza a ação desejada a obtenção de uma vantagem ou supressão de uma desvantagem, como é o caso da isenção fiscal ou, ainda, do Imposto sobre Circulação de Mercadorias e Serviços de Transporte Intermunicipal e Interestadual e de Comunicações com função extrafiscal ambiental (ICMS Ecológico), cuja técnica de incentivo consiste em contemplar com maiores repasses da receita do ICMS os Municípios que têm práticas em favor da proteção do meio ambiente.

Fala-se aqui na chamada extrafiscalidade do tributo, que consiste, segundo Paulo de Barros Carvalho (2003, p. 228-229), na "forma de manejar elementos jurídicos usados na configuração dos tributos, perseguindo objetivos alheios aos meramente arrecadatórios":

A utilização extrafiscal do tributo visa, acima de tudo, induzir a conduta dos contri-
buintes. Ao contrário do que se almeja através da função tributária tradicional (obten-
ção de recursos para o financiamento das atividades estatais), utilizando-se da extra-
fiscalidade o Estado busca, muitas vezes, uma 'redução da arrecadação', seja através
da imposição de altas cargas tributárias às condutas que visa reduzir, seja através da
concessão de incentivos fiscais àqueles que se adaptam à conduta almejada (TUPIAS-
SU, 2006, p. 120).

São mais eficazes os incentivos fiscais para o controle da poluição, pois o agente avaliará a conveniência de optar por eles uma vez que, em geral, viabilizam a realização de seus objetivos comerciais. Uma política tributária que tenha por objetivo minimizar e prevenir os impactos ambientais da atividade econômica deve privilegiar os incentivos econômicos ao invés de aumentar a carga tributária.

Quando tem função extrafiscal, o tributo abandona seu papel de mero financiador da atividade do Estado, provendo-o dos recursos necessários ao cumprimento de seus deveres e tendo a finalidade exclusiva de abastecer os cofres públicos, o que se denomina função arrecadatória ou fiscal, para ser utilizado para direcionar a conduta dos contribuintes. A extrafiscalidade é uma forma de tributação que permite a valorização da liberdade do contribuinte, que deve optar por um agravamento da carga tributária, ou alteração da conduta socialmente indesejada. Assim, funciona como um instrumento eficaz de indução. 
O Estado pode valer-se da extrafiscalidade do tributo para materializar vontades estatais, impondo valores e o peso da política traçada por ele com intuito de cumprir a sua tarefa de buscar construir uma sociedade mais justa, livre e solidária. Observa-se, portanto, o caráter social do tributo, que exerce finalidade voltada para o bem comum, "devendo ser ressaltada, especificamente no caso aqui em tela, a importância de sua utilização como instrumento de implementação de políticas de proteção ao meio ambiente e ao desenvolvimento sustentável" (TUPIASSU, 2006, p.123).

Mas é preciso afastar a concepção restritiva de que esta qualidade do tributo somente se verifica quando os critérios ecológicos se apresentam dentre os elementos de sua regra-matriz de incidência tributária, despindo-os de finalidade precipuamente arrecadatória. Isso porque, no que tange à questão exclusiva da destinação da receita, por exemplo, "é bem possível que se observe a existência de receita tributária afetada a fins ecológicos, sem que a estrutura da exação importe qualquer estímulo à preservação ambiental”, ressalta a autora (TUPIASSU, 2006, p.126).

Assim, mister admitir que tributos eminentemente arrecadatórios e sem afetação ecológica específica podem redundar em efeitos extrafiscais, podendo ser utilizados como instrumentos de política ambiental por meio da inserção de elementos indutivos sem seu bojo.

E é isso que ocorre com o ICMS Ecológico, pois, mesmo que os fatores ecológicos não estejam incluídos dentre os critérios da regra-matriz de incidência tributária do ICMS, o critério ecológico introduzido no repasse de sua receita traduz-se em meio extrafiscal para a implementação da defesa do meio ambiente.

Nas palavras de Scaff e Tupiassu (2005, p.735), “[...] a política do ICMS Ecológico representa uma clara intervenção positiva do Estado, por meio da utilização de uma forma de subsídio, tal como um incentivo fiscal intergovernamental". Esse incentivo representa um instrumento econômico de uma política pública que surte efeito extrafiscal com vistas à consecução de uma finalidade constitucional de preservação, promovendo justiça fiscal, e influenciando na ação voluntária dos Municípios que buscam um aumento de receita, e uma melhor qualidade de vida para suas populações:

A transferência, segundo critérios ecológicos, da parcela do ICMS pertencente aos Municípios representa um verdadeiro redimensionamento de valores, nos dois sentidos que o termo pode adquirir. De um lado, porque tal política realmente altera o montante de verbas orçamentárias a ser recebido por cada Município, beneficiando os que contribuem com a melhoria da qualidade de vida da população. Por outro lado, e principalmente, porque a implementação de tal política resulta, naturalmente, numa 
nova forma de compreender os valores que pautam o desenvolvimento local. Doravante, não apenas a implementação de indústrias poluentes traz ganhos financeiros para os municípios; a preservação de áreas verdes, a construção de redes de esgoto, escolas e hospitais também passam a ser sinônimo de aumento da receita e desenvolvimento. (TUPIASSU, 2006, p. 247).

Com efeito, o ICMS Ecológico é um importante instrumento que pode ser utilizado nos Estados como instrumento de política pública que concilie Tributação e Preservação do Meio Ambiente, contribuindo para a imposição de um conteúdo verdadeiramente substancial à tributação, e o que é mais importante, sem criar, necessariamente, um novo tributo. Ele pode ser utilizado pelos Municípios brasileiros com a finalidade de programar uma política pública de preservação ambiental por meio do aumento de suas respectivas porcentagens na participação nas receitas geradas pelo ICMS de seus Estados, na medida em que aderirem uma postura de desenvolvimento econômico associado à proteção do meio ambiente.

$\mathrm{O}$ atual sistema constitucional tributário brasileiro é apresentado sobre tríplice aspecto: o da repartição de competências tributárias entre a União, os Estados, o Distrito Federal e os Municípios; o dos princípios e limitações do poder de tributar; e o da partilha direta e indireta do produto da arrecadação dos impostos entre as pessoas políticas da federação. "Para a maioria dos autores, a presença do sistema de partilha de receitas no capítulo do sistema tributário constitui um grande equívoco, por se tratar de assunto que foge ao Direito Tributário, sendo matéria afeita às Finanças Públicas" (COELHO, 2003, p. 367).

Os Estados dividem com os Municípios situados em seus territórios a receita do ICMS, em razão do disposto no Art. 158, IV da CF/88:

\footnotetext{
Art. 158, CF. Pertencem aos Municípios:

$[\ldots]$

IV - vinte e cinco por cento do produto da arrecadação do imposto do Estado sobre operações relativas à circulação de mercadorias e sobre prestações de serviços de transporte interestadual e intermunicipal e de comunicação.
}

A forma pela qual será realizado esse repasse do Estado para os Municípios, está prevista no Art. 158, p.u, I e II, CF/88:

\footnotetext{
Art. 158, CF. [...]

Parágrafo único - As parcelas de receita pertencentes aos Municípios, mencionadas no inciso IV, serão creditadas conforme os seguintes critérios:

I - três quartos, no mínimo, na proporção do valor adicionado nas operações relativas à circulação de mercadorias e nas prestações de serviços, realizadas em seus territó-
} 
rios.

II - até um quarto, de acordo com o que dispuser lei estadual ou, no caso dos Territórios, lei federal

Em relação ao valor adicionado, a Lei Complementar $n^{0} .63$, de 11.01.1990, em seu Art. $3^{\circ}, \S 1^{\mathrm{o}}$, define:

Art. 3, LC n'. 63/90 [...].

$\S 1^{\circ}$. O valor adicionado corresponderá, para cada Município:

I - ao valor das mercadorias saídas, acrescido do valor das prestações de serviços, no seu território, deduzido o valor das mercadorias entradas, em cada ano civil.

GRÁFICO 1 - Repartição da Receita do ICMS entre os Municípios do Estado

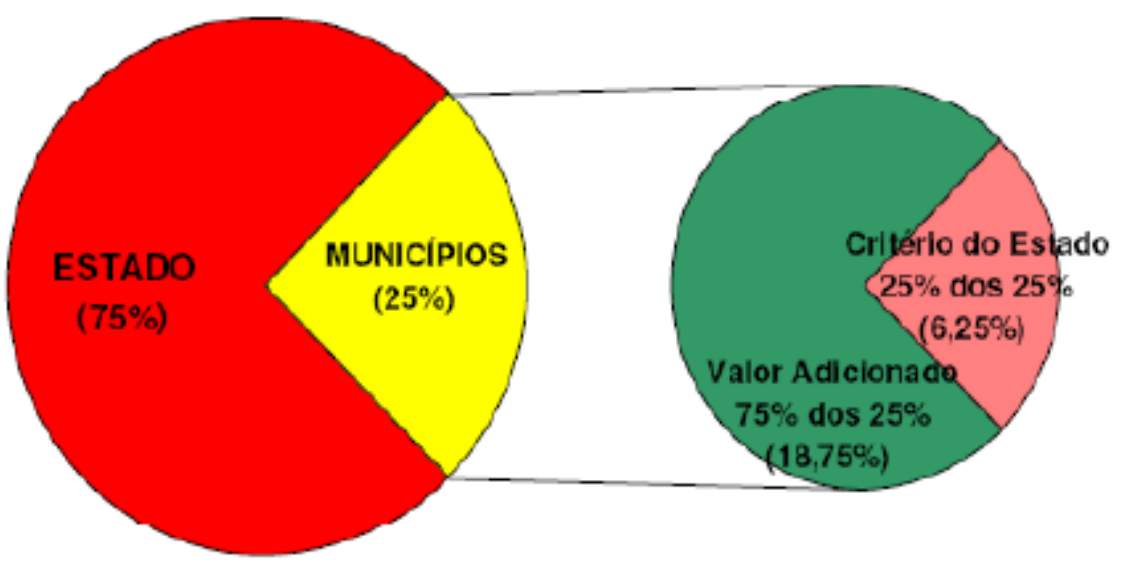

Fonte: RIBEIRO (2008, p.14)

O Art. $158, \mathrm{IV}, \mathrm{CF} / 88$ estabelece que $25 \%$ (vinte e cinco por cento) do ICMS deve ser repassados aos Municípios; $75 \%$ (setenta e cinco por cento) dos 25\% (vinte e cinco por cento) constituem a parcela determinada por meio de rígida aferição decorrente da participação dos próprios Municípios na arrecadação do ICMS (VAF). O percentual restante e correspondente a $25 \%$ pode ser distribuído de acordo com o que dispuser a lei estadual. Nesse percentual, situa-se a possibilidade do emprego da utilização ambiental do ICMS, o ICMS Ecológico

O ICMS Ecológico, conforme ficou conhecido o critério de repartição da receita do ICMS, buscando a divulgação e popularização do termo, é uma locução utilizada com certa impropriedade, pois vincula a própria espécie tributária do ICMS à questão ambiental. O que ocorre, na verdade é a destinação recursos financeiros provenientes de sua arrecadação 
por meio de um mecanismo próprio do federalismo fiscal (SCAFF; TUPIASSU, 2005, p.735). Como explica Éderson Pires (2001):

Na verdade não se trata de uma nova modalidade de tributo ou uma espécie de ICMS, parecendo mesmo que a denominação é imprópria a identificar o seu verdadeiro significado, de vez que não há qualquer vinculação do fato gerador do ICMS a atividades de cunho ambiental. Da mesma forma, como não poderia deixar de ser, não há vinculação específica da receita do tributo para financiar atividades ambientais. Não obstante, a expressão já popularizada ICMS ECOLÓGICO está a indicar uma maior destinação de parcela do ICMS aos Municípios em razão de sua adequação a níveis legalmente estabelecidos de preservação ambiental e de melhoria da qualidade de vida, observados os limites constitucionais de distribuição de receitas tributárias e os critérios técnicos definidos em lei.

Ao ICMS Ecológico são atribuídas duas funções primordiais: a compensatória e a incentivadora (BENSUSAN; FREITAS, 2002, p. 251). A função compensatória beneficia os Municípios que sofrem limitações quanto ao gerenciamento de seus territórios, em função da existência de Unidades de Conservação ou áreas com restrições de uso. Esses Municípios geralmente recebem menos dinheiro quando da repartição feita pelo Estado, pois normalmente têm menos atividades geradoras de arrecadação do ICMS ligadas ao comércio, indústria e prestação de serviços. A função incentivadora atua como incentivo aos Municípios, despertando o interesse em criar ou ampliar áreas de conservação ou outros critérios relevantes para o ICMS Ecológico, inclusive quanto aos aspectos qualitativos.

Anderson Orestes Cavalcante Lobato e Gilson César Borges de Almeida, (apud MURARO, 2006, p. 110) salientam que o ICMS ecológico surgiu com o objetivo de compensação, isto é, pretendia ser um instrumento de recompensa para os Municípios que possuíam no seu território áreas protegidas, constituídas por meio de unidades de conservação ou mananciais de abastecimento de água, que não podiam ser utilizadas e eram analisadas como um bloqueio ao desenvolvimento econômico.

Necessário ressaltar que o intuito inicialmente compensatório conferido ao instituto logo se viu substituído por uma conseqüência incrementadora, tendo em vista que um número crescente de Municípios passou a implementar políticas públicas ambientais neste sentido, almejando receber uma parte dos valores distribuídos segundo tais critérios. Para Lobato e Almeida (apud MURARO, 2006, p. 110):

O ICMS ecológico transforma-se em um instrumento de incentivo de maneira que os Municípios viram-se estimulados a adotar medidas tendentes à conservação ambiental 
e ao desenvolvimento sustentável. Ocorreu na realidade uma indução para a criação de unidades de conservação ou para a manutenção dos já existentes, incorporando novas tecnologias na promoção do equilíbrio ecológico, o que trouxe como conseqüência um maior desenvolvimento econômico.

A finalidade imediata do ICMS Ecológico é estabelecida de acordo com as prioridades de cada Estado da Federação, estimulando ações de saneamento básico, a manutenção de sistemas de disposição final de resíduos sólidos e redes de tratamento de esgoto, a manutenção de mananciais de abastecimento público de água, a criação e manutenção de Unidades de Conservação, conservação da biodiversidade, o apoio às nações indígenas, o controle das queimadas, a conservação dos solos, a estruturação de políticas municipais de meio ambiente, a dotação orçamentária para o atendimento a demandas ambientais da população local, dentre outros.

Pioneiramente, o instituto foi concebido no Estado do Paraná, em 1991, e hoje já se encontra efetivamente implantado ou fase de implantação também em Estados como São Paulo, Minas Gerais, Rondônia, Amapá, Rio Grande do Sul, Mato Grosso, Mato Grosso do Sul, Pernambuco, Tocantins, Acre, Rio de Janeiro, e Ceará:

\begin{tabular}{|c|c|c|c|}
\hline Estado & Legislação (Obs.:) & $\%$ & $\begin{array}{l}\text { Critérios para Receber o ICMS Ecológico (\% do } \\
\text { ICMS Ecológico por critério) }\end{array}$ \\
\hline \multirow[t]{2}{*}{ Paraná } & \multirow{2}{*}{$\begin{array}{c}\text { LC n. } 59 / 91 ; \text { Decreto } \\
\text { Estadual N. } 2.791 / 96 \\
\text { Decreto Estadual N. } \\
3.446 / 97 \\
\text { Decreto Estadual N. } \\
1.529 / 07 \\
\text { Resoluções da SEMA }\end{array}$} & \multirow[t]{2}{*}{$5 \%$} & $\begin{array}{l}\text { Municipios que possuem Mananciais de Abastecimento } \\
\qquad(2,5 \%)\end{array}$ \\
\hline & & & $\begin{array}{c}\text { Municipios que possuem Unidades de Conservação } \\
\text { Municipais, Estaduais e Federais, Áreas Indigenas, } \\
\text { Faxinais, RPPN's Áreas de Preservação Permanente } \\
\text { e/ou Reserva Legal }(2,5 \%)\end{array}$ \\
\hline São Paulo & $\begin{array}{l}\text { Lei Estadual N. } \\
8.510 / 93\end{array}$ & $0,5 \%$ & $\begin{array}{l}\text { Areas Especialmente protegidas }(0,5 \%) \text { (Recebem o } \\
\text { beneficio apenas Unidades de Conservação Estaduais) }\end{array}$ \\
\hline \multirow[t]{2}{*}{$\begin{array}{l}\text { Minas } \\
\text { Gerais }\end{array}$} & \multirow{2}{*}{$\begin{array}{c}\text { Lei Estadual N. }^{\circ} \\
12.040 / 95 \text { (Lei Robin } \\
\text { Hood) revogada pela } \\
\text { Lei Estadual N. }^{\circ} \\
13.803 / 00\end{array}$} & \multirow[t]{2}{*}{$1 \%$} & $\begin{array}{c}\text { IC - Indice de Conservação - referente a unidades de } \\
\text { conservação e outras áreas protegidas (incluindo RPPN) } \\
(0,5 \%)\end{array}$ \\
\hline & & & $\begin{array}{l}\text { ISA - Indice de Saneamento Ambiental - referente a } \\
\text { aterros sanitários, estação de tratamento de esgoto e } \\
\text { usinas de compostagem }(0,5 \%)\end{array}$ \\
\hline \multirow[t]{3}{*}{$\begin{array}{l}\text { Rio de } \\
\text { Janeiro }\end{array}$} & \multirow[t]{3}{*}{$\begin{array}{l}\text { LE n. } 2.664 / 96 ; \text { LE n. } \\
\quad 5.100 / 07\end{array}$} & \multirow[t]{3}{*}{$\begin{array}{l}1 \%(\mathrm{em} \\
2009)^{7}\end{array}$} & $\begin{array}{l}\text { Unidades de Conservação ( } 0,45 \% \text {, sendo que as } \\
\text { prefeituras que criarem suas próprias UC's terão direito } \\
\text { a } 0,20 \% \text { deste percentual) }\end{array}$ \\
\hline & & & Qualidade da água $(0,30 \%)$ \\
\hline & & & Administração dos Residuos Sólidos $(0,25 \%)$ \\
\hline \multirow[t]{3}{*}{ Pernambuco } & \multirow{3}{*}{$\begin{array}{l}\text { Lei Estadual N. } \\
11.899 / 00 \\
\text { (neste Estado o imposto } \\
\text { é denominado de }\end{array}$} & \multirow[t]{3}{*}{$15 \%$} & $\begin{array}{c}\text { Unidades de Conservação estaduais, municipais e } \\
\text { federais (1\%) }\end{array}$ \\
\hline & & & Usinas de Compostagem e Aterro Sanitário (5\%) \\
\hline & & & Desempenho na Área de Educação - de acordo com o \\
\hline
\end{tabular}




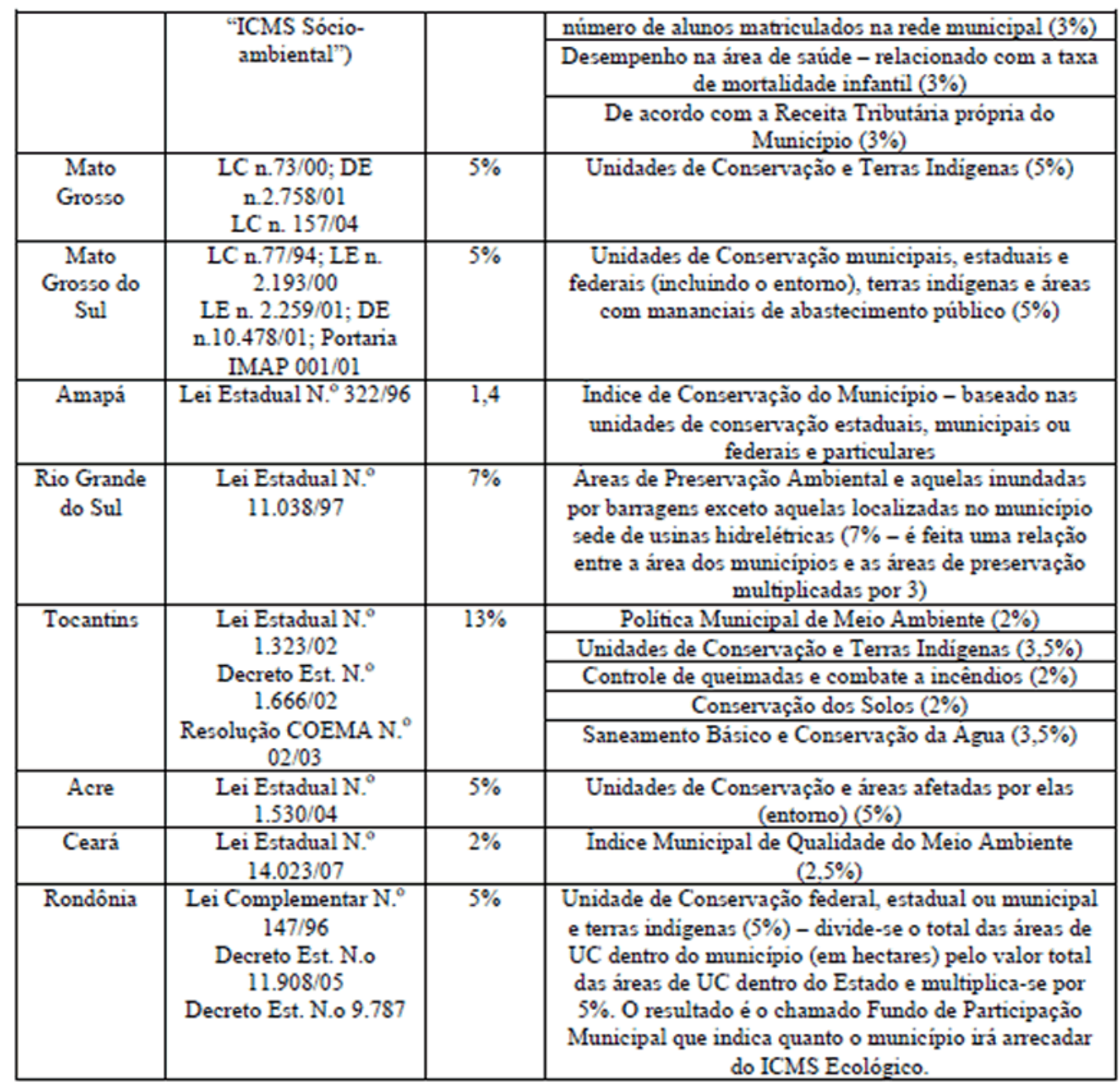

Tabela 1 - Estados Brasileiros que já Instituíram ICMS Ecológico, Legislações Estaduais Pertinentes e Critérios para Recebimento de Repasse pelos Municípios.

Fonte: RIBEIRO (2008, p.14)

Cada um dos Estados que se utiliza do sistema de repartição da receita do ICMS que privilegia a questão ambiental estabelece diferentes montantes a serem repartidos segundo a apreciação de diferentes aspectos ecológicos sociais. Scaff e Tupiassu (2005, p. 736) entendem que a concretização do ICMS Ecológico não exige complexas alterações legislativas. Esquivando-se das longas discussões no Congresso Nacional, responsáveis por anos de tramitação das propostas que visam a alterar a legislação tributária ou emendar a Constituição, a implementação do ICMS Ecológico normalmente depende apenas de lei estadual, uma vez que os princípios basilares da repartição financeira já se encontram na Constituição Federal e na maioria das Constituições Estaduais. 
Conforme comumente ocorre, por meio dos debates estaduais são estabelecidos diversos critérios de mensuração do valor a ser recebido pelos Municípios a título de repasse financeiro, sempre levando em conta as peculiaridades naturais de cada região. Daí porque cada um dos Estados que se utiliza do sistema estabelece diferentes montantes a serem repartidos segundo a apreciação de diferentes aspectos ecológico-sociais.

Conforme a tabela elaborada por Caroline Faria (2009), treze dos vinte e seis Estados da Federação já instituíram o ICMS Ecológico. Os outros Estados ainda estudam a possibilidade de aplicação desse tipo de repartição de receita do imposto e, na maioria deles, já existem projetos de lei para a aplicação do imposto na preservação ambiental. Os atuais debates, neste sentido, estão relacionados no seguinte quadro:

\begin{tabular}{|l|c|c|}
\hline \multirow{2}{*}{ ESTADO } & $\begin{array}{c}\text { Cnidades de Conservação, Terras } \\
\text { Indígenas e outras Áreas } \\
\text { Especialmente Protegidas (\%) }\end{array}$ & $\begin{array}{c}\text { Outros critérios ambientais } \\
(\%)\end{array}$ \\
\hline Bahia & 2,5 & 2,5 \\
\hline Espírito Santo & 5,0 & 3,0 \\
\hline Santa Catarina & 1,25 & 3,75 \\
\hline Pará & 8,75 & 5,0 \\
\hline Rio Grande do Norte & 5,0 & - \\
\hline Goiás & 4,0 & 1,0 \\
\hline $\begin{array}{c}\text { NOTAS: (1) Espírito Santo apresenta cinco propostas alternativas de Lei, sendo que os critérios e os } \\
\text { percentuais constante na tabela, diz respeito a primeira proposta. } \\
\text { (2) Santa Catarina apresenta seis propostas alternativas, sendo que os critérios e os percentuais } \\
\text { constante na tabela, dizem respeito a uma proposta de consenso liderada pelo Conselho Estadual } \\
\text { do Meio Ambiente (CONSEMA). }\end{array}$ \\
\hline
\end{tabular}

Tabela 2 - Estados Brasileiros com ICMS Ecológico em Fase de Discussão e Percentuais Propostos para os Repasses em Relação às Unidades de Conservação e Outros.

FONTE: MARRA, 2005, p. 20, (ADAPTADO)

O que é relevante na adoção de política pública de tributação ambiental é que não há elevação da carga tributária, pois não se cria tributo novo e por isso, não é aumentado o ônus financeiro do Estado. Trata-se, tão-somente, da adoção de parâmetros ambientalmente relevantes para a repartição das receitas arrecadadas (SCAFF; TUPIASSU, 2005, p. 736).

$\mathrm{Na}$ prática, o que aconteceu foi uma "reciclagem dos recursos arrecadados com o ICMS”, que antes já era distribuído por outros critérios de participação dos Municípios. Outro aspecto importante do ICMS Ecológico é que o ônus operacional é mínimo. Normalmente, para a realização do cadastro das unidades de conservação e quantificação dos itens elencados pela legislação, cuja atualização deve ser constante a fim de proporcionar a perfeita consonância dos repasses financeiros com a realidade municipal, a própria estrutura administrativa já existente pode ser utilizada (SCAFF; TUPIASSU, 2005, p.738). 


\section{O ICMS ECOLÓGICO NO ESTADO DE RONDÔNIA: LEGISLAÇÃO PERTINENTE E CÁLCULO DO PERCENTUAL DESTINADO AOS MUNICÍPIOS DO ESTADO}

O ICMS Ecológico foi instituído em Rondônia pela Lei Complementar Estadual $\mathrm{n}^{\circ}$ 147 de 15 de janeiro de 1996, regulamentada pelo Decreto Estadual n 9.787 de 20.12.2001, que, por sua vez, foi revogado pelo Art. 26 do Decreto $\mathrm{n}^{\mathrm{o}} 11.908$ de 12.12.2005.

O Art. 158, CF/88 determina o percentual de repasse pelo Estado aos Municípios da receita do ICMS, possibilitando a destinação específica para criação do ICMS Ecológico em cada Estado.

Já o Art. 127, § 3º Constituição do Estado de Rondônia de 28 de setembro de 1989 (CE/89) define que as parcelas de receita do ICMS pertencentes ao Município:

Art. 127, CE. O Estado e os Municípios poderão instituir os tributos previstos nos incisos I e II do art. 145 da Constituição Federal, bem como o de contribuição de melhoria pela valorização do imóvel decorrente de obras públicas.

$[\ldots]$

$\S 3^{\circ}$. As parcelas de receita pertencentes ao Município, concernentes ao imposto sobre as operações relativas à circulação de mercadorias e sobre prestações de serviços de transportes interestadual e intermunicipal e de comunicação serão creditadas conforme os seguintes critérios:

a) quatro quintos na proporção do valor adicionados nas operações realizadas em seu território, imediatamente após a arrecadação;

b) um quinto, de acordo com o que dispuser a lei estadual.

Percebe-se que a Carta Estadual determina um percentual maior - $80 \%$ (oitenta por cento) - do que os 75\% (setenta e cinco por cento) mínimos reservados ao VAF pela Constituição Federal. De plano, pode-se confirmar que não há afronta à Constituição Federal, vez que esta prescreve apenas o valor mínimo, podendo o Estado-membro aumentá-lo livremente.

Conseqüentemente, no Estado de Rondônia o valor da parte da arrecadação do ICMS destinado livremente do Estado para os Municípios por meio de lei estadual ficou reduzido a 20\% (vinte por cento), o que, novamente, não encontra óbice nas disposições da $\mathrm{CF} / 88$, porque esta definiu apenas o percentual máximo de $25 \%$ (vinte e cinco por cento) para destinação desta natureza.

Embora até aqui não se encontre conflitos entre a $\mathrm{CF} / 88$ e a $\mathrm{CE} / 89$, vale observar a redação do Art. 158, parágrafo único, II, parte final, CF/88: 


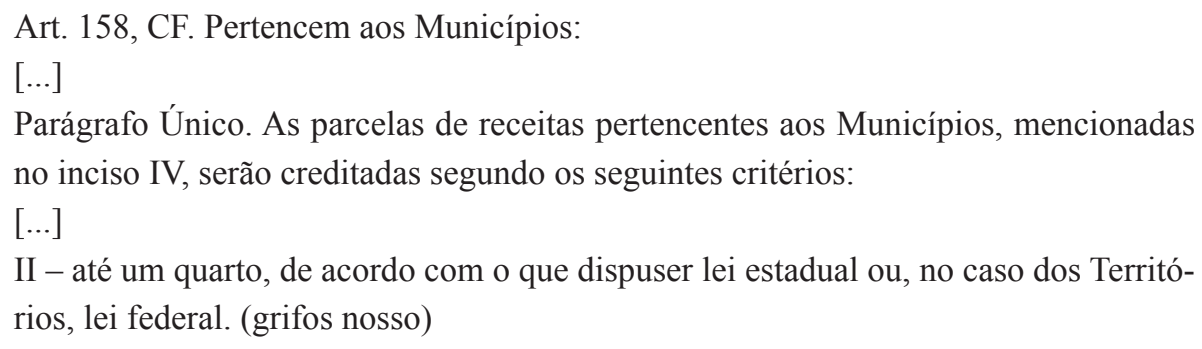

Ocorre que a $\mathrm{CF} / 88$ determina que, no máximo, $25 \%$ (vinte e cinco por cento) da receita do ICMS sejam distribuídos aos Municípios conforme bem entender o Estado-membro. Contudo, os critérios e porcentagem adotados para isso deverão ser definidos por meio de lei estadual. Então, deve-se questionar se a Assembléia Legislativa de Rondônia equivocou-se ao lançar mão da Constituição Estadual para tanto, vez que há reserva legal para a lei estadual.

Segundo a interpretação do Art. 25, CF/88 que leva em conta a teoria do Poder Constituinte, o que não for organização e funcionamento do Estado-membro, ou seja, não tratar de estruturação do Estado-membro, de suas funções e de seus órgãos (assuntos materialmente constitucionais) não poderá ser conteúdo da Constituição Estadual e sim de lei ordinária estadual, em prestígio ao princípio da separação dos poderes positivado no Art. $2^{\circ}, \mathrm{CF} / 88$. A Constituição Estadual não poderia tratar de matéria reservada à lei ordinária estadual, pois inibe a participação do Poder Executivo, que necessariamente deve sancionar as lei infraconstitucionais, ou mesmo dos outros órgãos que têm iniciativa no processo de formação das leis. O sentido material da Constituição estadual deve ser extraído da Constituição Federal, servindo as matérias que tratam da organização do Estado contidas na constituição Federal como paradigma para os elaboradores da Carta do Estado-membro. Mas, deve-se admitir que a discriminação das matérias formal ou materialmente constitucionais, contidas no corpo de uma Constituição Estadual, é tarefa difícil diante, principalmente, do modelo residual de competências conferidas ao Estado8.

O fato de a Constituição Federal exceder-se no texto tratando de temas que a doutrina costuma classificar como substancialmente não-constitucionais não tem o condão de permitir que o "Poder Constituinte Decorrente" também o faça. A ocorrência dessa situação em relação ao Poder Constituinte Originário é plenamente tolerada em face de sua natureza: não se subordina a qualquer autoridade e a Constituição, que é fruto de seu trabalho, é o início de toda normatividade jurídico-positiva de um Estado, sem compromisso com a ordem anterior. 
Outra questão a ser elucidada é a de o Art. 161, I, CF/88 reservar à lei complementar federal definir o VAF previsto no Art. 158, p.u, I, CF/88. Diante da disposição do Art. 127, § $3^{\circ}$, "a" e "b", CE/89, o Governador do Estado de Rondônia interpôs-se ação direta de inconstitucionalidade no ano de promulgação da Constituição Estadual (1989) em face da Assembléia Legislativa do Estado:

EMENTA: AÇÃO DIRETA DE INCONSTITUCIONALIDADE. ESTADO DE RONDONIA. INCS. A E B DO $\S 3^{\circ}$ DO ART. 127 DA CONSTITUIÇÃO ESTADUAL. ALEGADA INVASAO DE COMPETÊNCIA DO LEGISLADOR COMPLEMENTAR FEDERAL. PREVISTA NO ART. 161 DA CONSTITUIÇÃO FEDERAL. Os dispositivos impugnados, ao fixarem em quatro quintos e um quinto, respectivamente, os percentuais relativos ao critério de creditamento, aos Municípios, das parcelas que lhes cabem no produto do ICMS, na forma prevista no art. 158, inc. IV e parágrafo único, incs. I e II, da Constituição Federal, ateve-se aos limites estabelecidos nos mencionados dispositivos, não incidindo na alegada inconstitucionalidade. Nenhuma censura, por igual, merece o primeiro texto impugnado, ao estabelecer, de pronto, em cumprimento ao disposto no art. $160 \mathrm{da} \mathrm{CF}$, o momento de entrega da parcela alusiva aos quatro quintos, matéria que, contrariamente ao sustentado na inicial, não foi reservada a lei complementar pelo art. 161, I, da mesma Carta.

Improcedência da ação. (ADI 95, Relator(a): Min. ILMAR GALVÃO, Tribunal Pleno, julgado em 18/10/1995, DJ 07-12-1995 PP-42607 EMENT VOL-01812-01 PP00001 REPUBLICAÇÃO: DJ 16-02-1996 PP-2996).(grifos nossos)

Em acórdão, os Ministros do STF decidiram que a Constituição Estadual de 1989, ao determinar que as parcelas da receita pertencentes ao Município concernentes ao rateio do ICMS deverão ser creditadas na forma de quatro quintos na proporção do valor adicionado e um quinto de acordo com o que determinar a lei estadual, não dispôs sobre matéria reservada à lei complementar, nem extrapolou os limites fixados pela $\mathrm{CF} / 88$, ou seja, três quartos, no mínimo, na proporção do VAF, e até um quinto, de acordo com o que dispuser a lei estadual. Sendo, por fim, julgada improcedente por unanimidade pela Corte Suprema.

Vale ressaltar que, no ano de 1989, ainda não havia sido editada a lei complementar federal prevista no mencionado Art.161, CF/88. E, mesmo depois, quando promulgada em 11 de janeiro 1990, a Lei Complementar no. 63, em seu Art. $3^{\circ}$, I e II, com texto idêntico ao da $\mathrm{CF} / 88$, fixaram-se os mesmos percentuais mínimos e máximos constantes do Art.158, p.u., I e II CF/88, o que confirma a tese de que cabe ao Estado-membro regular os critérios de cálculo dos percentuais para o repasse do ICMS aos Municípios. 
Conclui-se que, nesse ponto, a Constituição Estadual de 1989 não entra em conflito com outras normas ao definir o percentual da distribuição da receita do ICMS rondoniense.

Porém, a análise da CE/89 se apresenta outra interface quando contraposta à Lei Complementar Estadual no 115/94 (LCE/94), que disciplina a distribuição das parcelas do ICMS destinadas aos Municípios no Estado de Rondônia. Sucede que essa Lei Complementar Estadual, em dissonância à $\mathrm{CE} / 89$, determina os percentuais dentro dos limites permitidos pelo constituinte originário:

\footnotetext{
Art. $1^{\circ}, \mathrm{LCE} / 94$. As parcelas de receita pertencentes aos municípios, provenientes do produto da arrecadação de impostos de competência do Estado e de transferências por este recebidas, serão distribuídas da seguinte forma:

I - 75\% (setenta e cinco por cento), na proporção do valor adicionado nas operações relativas à circulação de mercadorias e nas prestações de serviços realizados em seu território;

II - 25\% (vinte e cinco por cento), em consonância com o disposto abaixo:

$[\ldots]$
}

A norma estadual infraconstitucional fere a CE/89, embora esteja em perfeita simetria com a $\mathrm{CF} / 88$, no que tange aos percentuais em discussão. Então, pode-se afirmar que, estando a lei infraconstitucional estadual adequada com a Constituição Federal, é dotada de constitucionalidade, pois inconstitucional seria a norma da própria Constituição Estadual que exerce competência que lhe é vedada pela Constituição Federal.

Não são todas as normas estaduais que retiram seu fundamento de validade na Constituição Estadual. Outras encontram esse fundamento diretamente na Constituição Federal. Por isso, nos Estados-membros, os atos jurídicos estaduais podem ser viciados por inconstitucionalidade sob duplo ângulo: frente à Constituição Federal e, nestas hipóteses, incluem-se as próprias Constituições Estaduais, e frente à Constituição Estadual.

Ferraz (1979, p.127-128) combate o fato de os constituintes decorrentes procurarem introduzir os valores e os fins da política social que desejam ver desenvolvidos em seus Estados, dando à Constituição Estadual um caráter de instrumento de ação governamental de forma que "se afaste cada vez mais do modelo tradicional, breve, simples, objetivo e restrito, para abranger normas das mais variadas espécies, via de regra, mais apropriadas à função legislativa”. E, nesse contexto, insere-se a inclusão do Art. 127, § $3^{\circ}, \mathrm{CE} / 89$, no qual o constituinte decorrente pratica um excesso. 
Vale aqui ressaltar que "o poder constituinte originário analisado do ponto de vista jurídico pode tudo, já o 'poder constituinte decorrente' só pode agir dentro do âmbito marcado na Constituição Federal” (IVO, 1997, p.102). O fato de a CF/88 ser ilimitada, incondicionada e insubordinada a qualquer outra norma não permite que a Constituição Estadual também o seja. E, por isso, impõe-se o limite prescrito no Art. 25, CF/88, que marca como campo de ação das Constituições Estaduais as normas de organização e regência próprias. Contempla-se o texto:

Art. 25, CF. Os Estados organizam-se e regem-se pelas Constituições e leis que adotarem, observados os princípios desta Constituição. (grifos nossos)

Isso significa que a Constituição do Estado-membro apenas disciplinará os órgãos verticais de governo, sua estrutura e relacionamento mútuo. Portanto, “o que não for organização e funcionamento do Estado-membro, ou seja, elaboração de normas constitucionais institutivas não poderá ser conteúdo da Constituição Estadual, e sim, de lei ordinária estadual” (IVO, 1997, p.103).

De forma mais precisa, pode-se afirmar que a Carta do Estado-membro tem autorização para abranger somente matéria substancialmente constitucional. O que, de plano, exclui a abordagem de matéria tributária e financeira em seu texto. Assim, a LCE/94 não é inconstitucional, vez que é a CE/89 que invade a competência da lei estadual ao dispor sobre matéria tributária e financeira, inserindo matéria formalmente constitucional em seu corpo. Em verdade, inconstitucional é o disposto na CE/89 perante o Art. 2, CF/88.

Enfim, não cabe tencionar pela inconstitucionalidade da lei complementar estadual que define os percentuais de participação dos municípios rondonienses na receita do ICMS, há quinze anos que, a propósito, nunca foi objeto de ADIN, nem de controle difuso de constitucionalidade.

Observação a ser feita é sobre o fato de o poder legislativo de Rondônia ter utilizado lei complementar para isso, embora a $\mathrm{CF} / 88$ não preveja a necessidade dessa espécie legislativa, deixando a cargo da lei estadual em sentido lato. Quanto à CE/89, conquanto tenha deixado os critérios de aferição da cota-parte do município a cargo de lei estadual em sentido estrito, não deve ser considerada por causa da inconstitucionalidade a pouco apontada.

Nesse caso, mesmo tratando-se de imperícia dos deputados rondonienses, não há impedimento à escolha da lei complementar estadual para disciplinar esta matéria. É a Lei Complementar Estadual no 147/96 (LCE/96) que instituiu o ICMS Ecológico no Estado de Rondônia, 
ao alterar e acrescentar dispositivos à LCE/94.

A LCE no. 115/94 disciplina a distribuição das parcelas do ICMS destinadas aos Municípios no Estado de Rondônia. Antes das alterações que sofreu possuía o seguinte texto:

Art. $1^{\circ}, \mathrm{LCE} \mathrm{n}^{\mathrm{o}} 115 / 94$. As parcelas de receita pertencentes aos municípios, provenientes do produto da arrecadação de impostos de competência do Estado e de transferências por este recebidas, serão distribuídas da seguinte forma:

I - 75\% (setenta e cinco por cento), na proporção do valor adicionado nas operações relativas à circulação de mercadorias e nas prestações de serviços realizados em seu território;

II - $25 \%$ (vinte e cinco por cento), em consonância com o disposto abaixo:

a) $0,5 \%$ (meio por cento) proporcional à superfície territorial;

b) $5 \%$ (cinco por cento) proporcional à produção agrícola, pecuária e extrativa;

c) $0,5 \%$ (meio por cento) proporcional à população;

d) $19 \%$ (dezenove por cento) em partes iguais.

Denota-se uma forma simplista na escolha desses parâmetros, pois se compromete $1 \%$ (um por cento) da receita do ICMS com o espaço territorial e com a população dos Municípios e 19\% (dezenove por cento) para a singela divisão igualitária. Predileção justificável para a época da edição dessa norma, devido às dificuldades de comunicação da região, como demonstra o relatório do acórdão proferido em face do requerimento de medida cautelar feito quando da propositura de Ação Direta de Inconstitucionalidade junto ao Supremo Tribunal Federal:

\footnotetext{
É de conhecimento público a complexibilidade das operações de arrecadação de tributos, seu controle, conferência e contabilização.

O Estado de Rondônia, pioneiro e incipiente, padece pela falta de comunicação entre suas comunas. Há municípios cuja comunicação se opera somente por meio fluvial sendo carentes de infra-estrutura arrecadadora, especialmente em Bancos Oficiais até por segurança, como determina a legislação estadual. (ADI-MC 95-1, Relator(a): Min. Sidney Sanches, Tribunal Pleno, julgado em 18/10/1995, DJ 12-10-1989 PP42607 EMENT VOL-01806-01 PP-00001 REPUBLICAÇÃO: DJ 27-10-1995).
}

No entanto, para a distribuição 5\% (cinco por cento) dos recursos restantes provenientes da receita do ICMS, evidencia-se a observância da função social do tributo estabelecida no Art.170, CF/88, ao determinar que o rateio da receita deve levar em consideração a produção agrícola, pecuária e extrativista de cada Município em proporção à do Estado, principais atividades econômicas do Estado de Rondônia à época da promulgação da LCE/94. 
E foi nesse contexto normativo que em 1996, inspirado pelos Estados do Paraná, São Paulo e Minas Gerais, que se instituiu o ICMS Ecológico no Estado de Rondônia, por meio da LCE/96.

A LCE/96 alterou as alíneas "d" e "e" do Art. 1", LCE/94, que passaram a vigorar com a seguinte redação:

Art. $1^{\circ}$ - As parcelas de receita pertencentes aos municípios, provenientes do produto da arrecadação de impostos de competência do Estado e de transferências por este recebidas, serão distribuídas da seguinte forma:

I- $-[\ldots]$

II $-25 \%$ (vinte e cinco por cento), em consonância com o disposto abaixo:

[...]

d) $14 \%$ (quatorze por cento) em partes iguais;

e) $5 \%$ (cinco por cento) proporcionais a ocupação territorial dos municípios com unidades de conservação.

A mudança ocorreu na alínea “d”, que reduziu o percentual de 19\% de divisão igualitária entre os Municípios para 14\%, cedendo 5\% (cinco por cento) para a distribuição da receita com base na proporção da ocupação territorial do respectivo Município por unidade de conservação. Em outras palavras, uma porção do parâmetro de divisão igualitária é substituída pelo ICMS Ecológico.

As unidades de conservação de que trata Art. 1 ${ }^{\circ}$, II, “e”, LCE/94, são áreas protegidas e estabelecidas em ecossistemas significativos do território estadual por ação administrativa dos governos Federal, Estadual e Municipal. Admitem-se quaisquer categorias de unidade de conservação, criadas por Leis ou Decretos municipal, estadual ou federal, desde que anualmente cadastradas junto à Secretaria de Estado de Desenvolvimento Ambiental de Rondônia (SEDAM/RO) pelas respectivas prefeituras dos territórios às quais pertençam, conforme dispõe o Decreto Estadual no. 11.908 de 12 de dezembro de 2005 (DCE/05):

Art. 10. As Prefeituras Municipais terão até o dia $1^{\circ}$ de março de cada ano para cadastrar junto à Secretaria de Estado de Desenvolvimento Ambiental - SEDAM, as áreas com unidades de conservação de que trata o $\S 2^{\circ}$ do artigo $3^{\circ}$ deste decreto.

De acordo com Art. $3^{\circ}$, LCE/96, são exemplos as seguintes categorias de unidade de conservação: Estação Ecológica, Reserva Biológica, Parque, Monumento Natural, Área de Pro- 
teção Ambiental, Reserva Indígena, Floresta, Reserva Extrativista.

Ainda segundo o Art. $4^{\circ}, \mathrm{LCE} / 96$, os percentuais relativos a cada Município que se enquadrar nas normas da presente Lei ou dos seus atos regulamentadores, serão calculados com base na proporção da ocupação territorial do respectivo Município por unidade de conservação. E o cálculo do montante da receita do ICMS destinado a cada Município é realizado da seguinte forma: divide-se o valor total de áreas de conservação (em hectares) do Município pelo valor total (em hectares) de área de conservação do Estado, multiplicando-se o valor por 5\%. Obtém-se a participação relativa deste Município. Este método determinado pelo Art. $3^{\circ}$ do DCE/05 disciplina a coleta de dados, a metodologia de cálculo do valor adicionado e demais fatores de agregação para fins de apuração dos índices de participação dos Municípios rondonienses no produto da arrecadação do ICMS:

Art. $3^{\circ} \mathrm{O}$ valor destinado ao município em decorrência de sua participação no produto da arrecadação do ICMS será determinado segundo os seguintes critérios:

$[\ldots]$

$\mathrm{V}-5 \%$ (cinco por cento) proporcionais à ocupação territorial dos municípios com unidades de conservação, considerando a relação entre a área total, em quilômetros quadrados, das unidades de conservação do município e a área total das unidades de conservação do estado no ano imediatamente anterior ao da apuração dos índices; $[\ldots]$

O decreto regulamentador elucidou o texto no Art. $4^{\circ}$ da LCE/96, que é demasiadamente vago. O Art. $5^{\circ}$, p.u., LCE no 147/96 também prevê a aplicação de redutores nos cálculos dos percentuais de participação dos Municípios na repartição do ICMS, em função da comprovação de invasões ou explorações ilegais, repartindo-se o montante reduzido entre aqueles Municípios cujas unidades de conservação estejam em acordo com a legislação ambiental.

Para tanto, o Art. 5 , caput, LCE no 147/96 dispõe que o órgão responsável pelo gerenciamento da política estadual de meio ambiente, a SEDAM/RO, em parceria com outras instituições que possuam atribuições correlatas, como por exemplo, o Instituto Chico Mendes de Conservação da Biodiversidade (ICMbio), adotará um sistema de cadastramento das unidades de conservação municipais, estaduais e federais, de modo que lhe permita conhecer o nível de agressão sofrida por invasões ou explorações ilegais. 
Esses dados são informados anualmente pela SEDAM/RO a Secretaria de Estado de Finanças (SEFIN/RO), podendo não sofrer alterações de um ano ao outro:

Art. 11. A Secretaria de Estado de Desenvolvimento Ambiental - SEDAM informará à Secretaria de Estado de Finanças - SEFIN e fará publicar no Diário Oficial do Estado, até o dia 31 de março de cada ano, os índices proporcionais de que trata o inciso $\mathrm{V}$ do artigo $3^{\circ}$ deste decreto em relação a cada município.

Compete à Gerência de Arrecadação da Coordenadoria da Receita Estadual a responsabilidade técnica pelo recebimento das informações, compilação de dados, cálculos e revisão, quando houver recursos, dos índices de participação dos Municípios. E a SEDAM/RO tem 15 (quinze) dias, contados da ciência da decisão, para informar a SEFIN/RO alterações decorrentes de ordem judicial em áreas com unidades de conservação dos Municípios. Em seguida, a Coordenadoria da Receita Estadual, tem até o dia 15 (quinze) do mês seguinte ao da data da ciência do ato para publicar as correções de índices decorrentes da ordem judicial.

\section{O IMPACTO DO ICMS ECOLÓGICO NA COMPENSAÇÃO FISCAL E NA CRIAÇÃO DE NOVAS UNIDADES DE CONSERVAÇÃO NO ESTADO DE RONDÔNIA}

Desde o início das primeiras discussões sobre o ICMS Ecológico, um dos pontos de maior destaque sempre foi a da necessidade de compensação aos Municípios que, por terem áreas de seu território afetadas por unidades de conservação de diversos graus de restrição, não poderiam dar a estas áreas uma destinações econômicas tradicionais, limitando dessa forma o seu desenvolvimento e a sua arrecadação.

A forma de verificar em números a compensação a esta afetação decorrente da aplicação do ICMS Ecológico consistiria em verificar a porcentagem de participação dos Municípios na receita do ICMS do exercício posterior à introdução deste instituto como critério de rateio, comparado com exercícios anteriores ao ano de 1997.

No entanto, tais informações não foram encontradas durante a pesquisa para a realização do presente trabalho, porque os órgãos responsáveis por esses dados, tais como SEFIN/ RO e SEDAM/RO, não dispõem de documentos oficiais referentes ao rateio do ICMS de anos anteriores ao exercício de 2002. 
Então, para conhecer quais os Municípios foram efetivamente compensados com a instituição do ICMS Ecológico, valer-se-á dos coeficientes gerados por este critério de repartição da receita do ICMS para o exercício de 2010, comparando-os com o antigo coeficiente produzido pela porcentagem de $19 \%$ do critério igualitário.

Porém, antes de comparar os coeficientes do fator ICMS Ecológico com o antigo fator de divisão uniforme, deve-se tomar nota da diferença entre os coeficientes gerados por este e os gerados pelo presente fator de divisão igualitária. Conforme a seguinte tabela:

\begin{tabular}{|c|c|c|}
\hline CRITÉRIO: & PORCENTAGEM & $\begin{array}{l}\text { COEFICIENTE INDIVIDUAL } \\
\text { CORRESPONDENTE A CADA UM } \\
\text { DOS ATUAIS } 52 \text { MUNICÍPIOS } \\
\end{array}$ \\
\hline 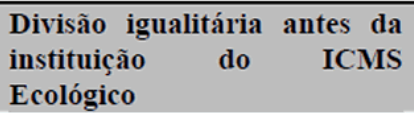 & $19 \%$ & 0,36538 \\
\hline 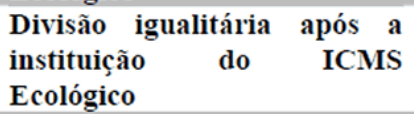 & $14 \%$ & 0,26923 \\
\hline $\begin{array}{l}\text { Diferença entre estes dois } \\
\text { critérios }\end{array}$ & $5 \%$ & 0,09615 \\
\hline
\end{tabular}

Tabela 3 - Coeficientes Gerados pelo Antigo e pelo Atual Fator de Divisão da Receita do ICMS no Estado de Rondônia.

FONTE: Anexo único da resolução conjunta No 001/2009/GAB/CRE/SEFIN, que estabelece os índices de participação dos municípios na arrecadação do ICMS para o exercício de 2010, conforme dispõe o artigo 158 da $\mathrm{CF} / 88$.

Se a criação do ICMS Ecológico reduziu em 0,09615 o coeficiente do fator de divisão igualitário, ter-se-ão como beneficiados com a edição da LCE/96 os Municípios que atingirem o coeficiente do fator unidade de conservação maior que 0,09615 , vez que, ao invés de perceber valores iguais aos demais Municípios, eles recebem uma porção maior por possuírem áreas protegidas em seus territórios.

Feita essa análise, constata-se que apenas 12 (doze), dos 52 (cinqüenta e dois) Municípios do Estado de Rondônia, foram efetivamente compensados com a alteração do fator de divisão igualitária para o fator Unidade de Conservação: 


\begin{tabular}{|c|c|c|c|c|}
\hline & MUNICIPIO & $\begin{array}{l}\text { COEFICIENTE } \\
\text { ICMS } \\
\text { ECOLÓGICO } \\
\end{array}$ & $\begin{array}{l}\text { RECEITA } \\
\text { GERADA PELO } \\
\text { ICMS } \\
\text { ECOLÓGICO } \\
\end{array}$ & $\begin{array}{c}\text { AUMENTONA } \\
\text { PARTICIPAÇÃO EM } \\
\text { RELAÇÃO AO CRITÉRIO } \\
\text { DE DIVISÃO IGUALITARIA }\end{array}$ \\
\hline 1 & Guajará-Minim & 1,22395 & RS 27.218.990.65 & RS $25.080 .744,85$ \\
\hline 2 & Porto Velho & 0,70824 & RS $15.750 .298,57$ & RS $13.612 .052,77$ \\
\hline 3 & São Francisco do Guaporé & 0,38000 & RS $8.450 .685,44$ & RS $6.312 .439,64$ \\
\hline 4 & Vilhena & 0,36166 & RS $8.042 .828,68$ & RS 5.904 .582 .88 \\
\hline 5 & Nova Mamoré & 0,27947 & RS 6.215.034,37 & RS 4.076.788,57 \\
\hline 6 & São Miguel do Guaporé & 0,27493 & RS $6 \cdot 114.070,92$ & RS 3.975.825,12 \\
\hline 7 & Ji-Paraná & 0,21659 & RS 4.816.668,32 & RS $2.678 .422,52$ \\
\hline 8 & Governador Jorge Teixeira & 0,18295 & RS 4.068.560,27 & RS $1.930 .314,47$ \\
\hline 9 & Pimenteiras do Oeste & 0,13183 & RS 2.931.720,69 & RS 793.474,89 \\
\hline 10 & Alta Floresta D'Oeste & 0,12067 & RS 2.683.537,40 & RS 545.291,60 \\
\hline 11 & Costa Marques & 0,10115 & RS $2.249 .439,03$ & RS $111.193,23$ \\
\hline 12 & Alto Alegre dos Parecis & 0,09653 & RS 2.146.696,49 & RS $8.450,69$ \\
\hline
\end{tabular}

Tabela 4 - Aumento da Participação dos Municípios do Estado de Rondônia na Participação na Receita do ICMS.

FONTE: Anexo único da resolução conjunta Nº 001/2009/GAB/CRE/SEFIN, que estabelece os índices de participação dos municípios na arrecadação do ICMS para o exercício de 2010, conforme dispõe o artigo 158 da $\mathrm{CF} / 88$.

Esses resultados são considerados de poucos efeitos comparados com os obtidos no Estado de Minas Gerais onde, por exemplo, o ICMS Ecológico beneficiou 660 (seiscentos e sessenta) Municípios dos 756 existentes em seu território, conforme sustenta Fernando Cesar da Veiga Neto (2000, p.77).

Outro ponto a ser verificado neste trabalho é o da resposta dos Municípios aos incentivos propostos pelo Governo do Estado nesta nova abordagem de política pública econômico-ambiental. Há várias maneiras de mensurar isso, como, por exemplo, analisando o aumento do número de Municípios que receberam repasses graças ao subcritério de unidades de conservação. Ocorre que os órgãos responsáveis pela dinâmica do cálculo do repasse do ICMS aos Municípios não possuem arquivos dos exercícios anteriores ao ano de 2002, o que impossibilita um demonstrativo dessa evolução. 
Entretanto, conforme dados do ano de 2007 obtidos por Vinicius Duarte Ribeiro (2008, p.23) junto ao Instituto Brasileiro do Meio Ambiente e dos Recursos Naturais Renováveis (IBAMA), o aumento de área protegida no Estado de Rondônia com o advento do ICMS Ecológico pode ser representado pelo seguinte gráfico, que demonstra as áreas de unidades de conservação no Estado de Rondônia nos três níveis de governo antes e depois da criação do ICMS ecológico, até o ano de 2007:

Gráfico 2 - Aumento da Área protegida no Estado de Rondônia com o Advento do ICMS Ecológico.

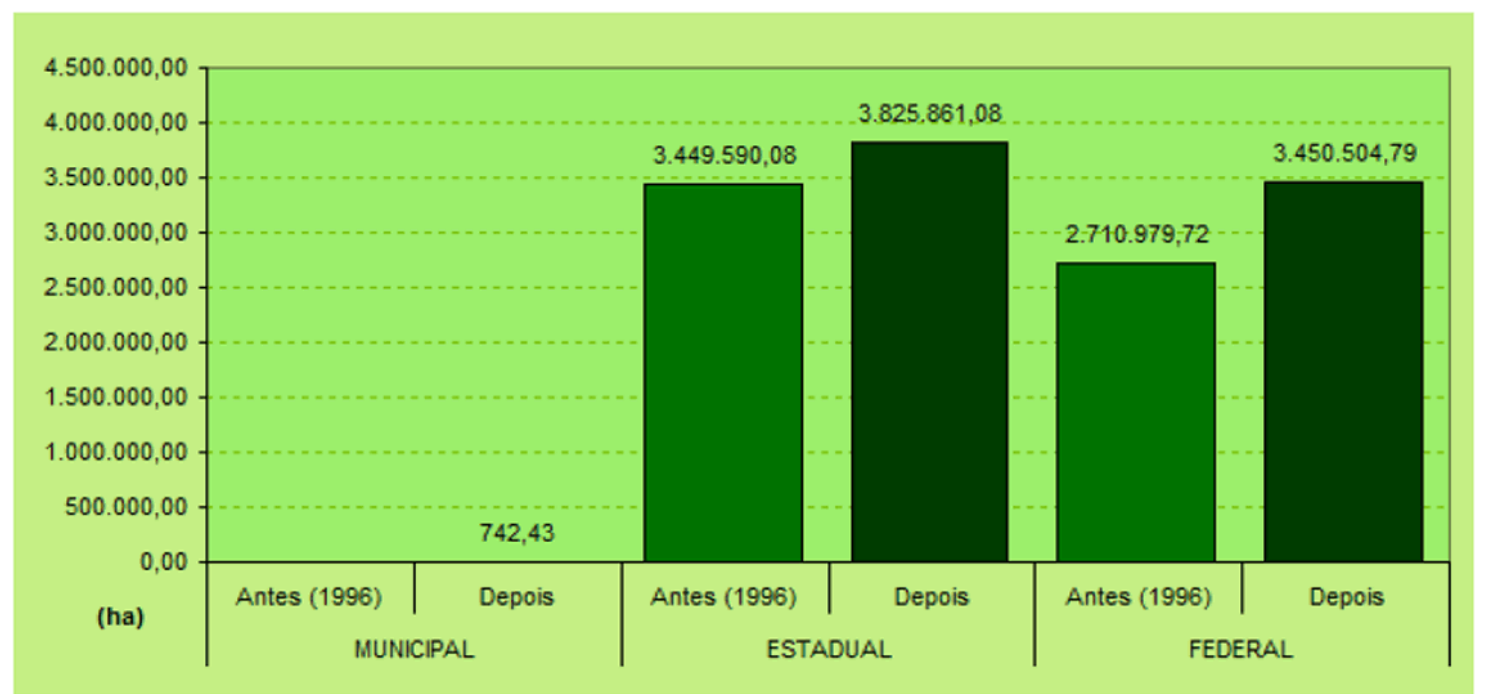

Fonte: Ribeiro (2008, p.23, ADAPTADO)

$\mathrm{O}$ aumento da área ambiental protegida neste período foi de 18,12\% (dezoito vírgula doze por cento), o equivalente a 1.116.538,5 hectares de novas áreas protegidas no território do Estado de Rondônia. Destaca-se o crescimento das unidades de conservação federais que representaram $66,25 \%$ (sessenta e seis virgula vinte e cinco por cento) dos 1.116.538,5 hectares.

Entretanto, os Municípios do Estado de Rondônia apresentaram ínfima participação na criação de novas unidades de conservação, não agindo positivamente diante do novo critério de repasse da receita do ICMS, ao passo que criaram apenas 742,43 (setecentos e quarenta e dois vírgula quarenta e três) hectares de novas unidades de conservação. Constata-se, então, que não ocorreu, como se esperava, uma "guerra fiscal ecológica" entre os Municípios rondonienses, 
uma vez que não se percebeu esforços para obtenção de maior de percentual deste montante de ICMS, o que poderia acarretar reais benefícios para toda a população que neles residem.

No que se refere às unidades de conservação existentes, vale ressaltar que o Art. 5o, LCE/96 determina que o órgão responsável pelo gerenciamento da política estadual de meio ambiente (SEDAM-RO), em parceria com outras instituições que possuam atribuições correlatas deve adotar um sistema de cadastramento das unidades de conservação municipais, estaduais e federais, de modo que lhe permita conhecer o nível de agressão sofrida por invasões ou explorações ilegais. Prescreve, inclusive, conseqüências financeiras para os Municípios nos quais as unidades de conservação agredidas se situarem:

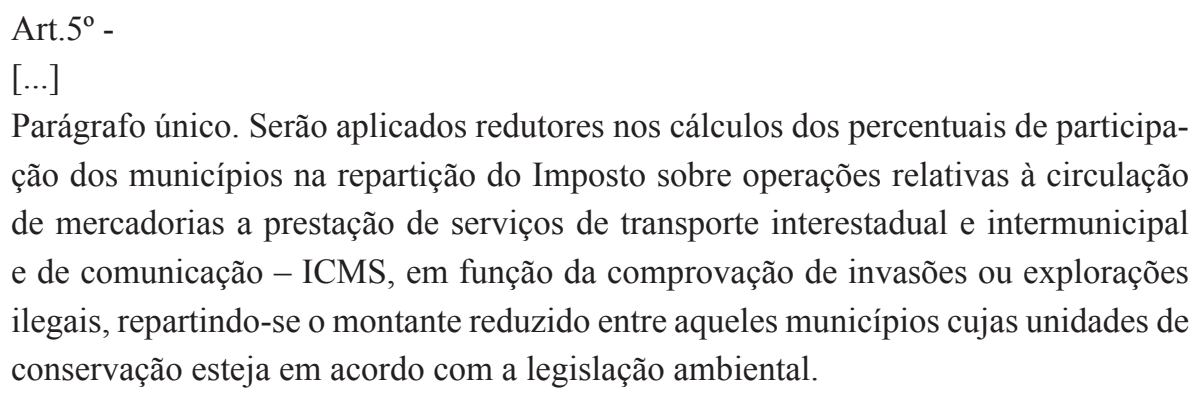
e de comunicação - ICMS, em função da comprovação de invasões ou explorações ilegais, repartindo-se o montante reduzido entre aqueles municípios cujas unidades de conservação esteja em acordo com a legislação ambiental.

No entanto, não se tem notícias da implementação de tal sistema para avaliar a qualidade das áreas protegidas. Na prática, os Municípios do Estado de Rondônia somente registram suas áreas protegidas junto a SEDAM-RO para se qualificarem para o ICMS Ecológico, não se sujeitando a qualquer controle da proteção dessas unidades de conservação.

O que acontece posteriormente, analisando-se gestão ou invasões, não afeta necessariamente o índice de participação na receita do ICMS. Isto implica que o ICMS Ecológico implantado no Estado de Rondônia pode ter incentivado a criação de novas áreas protegidas, mas não necessariamente acarretou sua plena proteção.

\section{CONCLUSÃO}

O presente estudo pretendeu ressaltar a importância e a possibilidade de utilização de instrumentos fiscais e econômicos enquanto elementos de políticas públicas voltadas para a 
proteção do meio ambiente, evidenciando a inclusão da proteção ambiental dentre os objetivos das políticas econômicas e fiscais. Tal premissa adquire grande valia quando colocada diante do fenômeno da evolução da participação do Estado nos processos econômicos.

$\mathrm{O}$ direito ao meio ambiente equilibrado, de mera categoria de interesse publico formal, passa a direito fundamental de terceira geração, conferido no âmbito internacional e pelo entendimento do Supremo Tribunal Federal, sendo notório o ganho de importância do preceito. Nessa perspectiva, o meio ambiente equilibrado sobressai como elemento da própria dignidade da pessoa humana, direito fundamental dos cidadãos e deve necessariamente ser levado em conta pelo Estado quando da definição dos objetivos de suas políticas econômico-fiscais.

Sob o ponto de vista econômico, frisa-se o paralelismo entre a proteção ao meio ambiente e o desenvolvimento, ambos representando valores essenciais para o mercado, e princípios da ordem econômica e social nacional, que determina ao Poder Público a adoção de medidas para direcionar seu equacionamento.

Os imperativos do desenvolvimento sustentável obrigam o cálculo das externalidades ambientais pelos sistemas produtivos, para favorecer a utilização de mecanismos econômicos e fiscais ecológicos. Em uma perspectiva fiscal a proteção do meio ambiente constitui fundamento do próprio poder de tributar que perde legitimidade se não servir à realização de tal princípio. Sobre tal pilar, abre-se a possibilidade e a necessidade da intersecção entre o Direito Tributário e o Direito Ambiental.

Ponto fundamental do estudo constitui, porém, a demonstração irrefutável da compatibilidade prática de tais fundamentos com a realidade e com a legislação nacional, o que se coloca de forma clara por meio da análise do ICMS Ecológico.

No Estado de Rondônia, o ICMS Ecológico foi introduzido com dois principais objetivos: compensar Municípios com áreas protegidas e agir como um incentivo aos Municípios para ampliar a área reservada para a proteção ambiental.

Enquanto instrumento de compensação, o ICMS ecológico foi parcialmente bem sucedido, ressaltando-se o problema da existência do controle da qualidade da proteção dada pelo Município às áreas protegidas pertencentes a seus territórios. Consequentemente, o rateio do ICMS, com base no critério ecológico, pode não observar causas de reduções no montante recebido por Município que tiver alguma unidade de conservação agredida. 
No tocante à promoção da criação de novas unidades de conservação o impacto foi menor, pois ocorreu um aumento de apenas de 18,12\% (dezoito vírgula doze por cento) das áreas protegidas no Estado de Rondônia, em onze anos de implementação do ICMS Ecológico. A eficiência do instituto nesse caso é ainda menor for considerado que ele não foi o único motivo do crescimento de áreas reservadas à proteção ambiental.

O ICMS Ecológico implantado no Estado de Rondônia merece algumas críticas, pois a gestão e o controle das áreas protegidas ainda devem ser implantados, a fim de estabelecer um sistema de avaliação de qualidade da manutenção dessas áreas e assim cumprir os objetivos almejados quando da sua instituição. Além disso, faz-se necessária a divulgação do funcionamento do ICMS Ecológico e de seus efeitos extrafiscais que fortaleçam a preservação do meio ambiente equilibrado, uma vez que os Municípios e o público em geral pouco conhecem este sistema. O acesso a tais mecanismos possibilitaria uma melhor educação ambiental e um maior reconhecimento da importância das unidades de conservação existentes nas terras rondonienses.

\section{REFERÊNCIAS}

ALMEIDA, Luciana Togeiro de. Política Ambiental: Uma Análise Econômica. São Paulo: UNESP, 1998.

APPIO, Eduardo. Controle Judicial das Políticas Públicas no Brasil. Curitiba: Juruá, 2005.

BENSUSAN, Nurit; FREITAS, Analuce. "ICMS Ecológico: Um Incentivo Fiscal para a Conservação da Biodiversidade". IN: BENSUSAN, N. (org.) Seria melhor mandar ladrilhar? Biodiversidade como, para que, por quê. Brasília: Universidade de Brasília, 2002.

CARVALHO, Paulo De Barros. Curso de Direito Tributário. São Paulo: Saraiva, 2003.

CAVALCANTI, Clóvis. Desenvolvimento e respeito à natureza: Uma introdução termodinâmica à economia da sustentabilidade. In FERREIRA, Leila da Costa; VIOLA, Eduardo. Incertezas de sustentabilidade na globalização. 2. Campinas: UNICAMP, 1996.

COÊLHO, Sacha Calmon Navarro. Curso de Direito Tributário Brasileiro. Rio de Janeiro: Forense, 2003.

DERANI, Cristiane. Direito Ambiental Econômico. São Paulo: Max Limonad, 2001.

FARIA, Caroline. ICMS Ecológico. 2009. Disponível em: <http://www.infoescola.com/ecologia/icms-ecologico/> Acesso em: 18 ago. 2009. 
FERRAZ, Ana Cândida Da Cunha. Poder Constituinte dos Estados-Membros. São Paulo: Revista dos Tribunais, 1979.

FOLADORI, Guillermo. Limites ao Desenvolvimento Sustentável. trad. Marise Manoel. Campinas-SP: Unicamp, 2001.

GUERRA, Sinclair Mallet-Guy; SUAREZ, Mirian Liliana Hinostroza. "Questões Econômicas e Implicações Ambientais: Visão Introdutória. In Revista de Direito Ambiental. Ano 2. n. 8. out-dez de 1997. São Paulo: Revista dos Tribunais, 1997.

IVO, Gabriel. Constituição Estadual: Competência para a Elaboração da Constituição do Estado-Membro. São Paulo: Max Limonad, 1997.

MARRA, Fernanda de Morais Santana. ICMS Ecológico como Instrumento para o Desenvolvimento Sustentável. 2005. Disponível em:

$<$ http://agata.ucg.br/formularios/ucg/institutos/nepjur/pdf/pos_08.pdf $>$ Acesso em: 20 out. 2009.

MURARO, Leonardo. A Extrafiscalidade Tributária no Brasil como Implementadora de Políticas Públicas para o Meio Ambiente. Dissertação (Mestrado em Direito) - Programa de Pós-Graduação em Direito da Universidade de Santa Cruz do Sul - UNISC, Santa Cruz Do Sul. 2006.

PIRES, Éderson. ICMS Ecológico - Aspectos Pontuais - Legislação Comparada, 2001. Disponível em: <www1.jus.com.br/doutrina/texto.asp?id=2328> Acesso em: 18 ago. 2009.

SCAFF, Fernando Facury; TUPIASSU, Lise Vieira da Costa. "Tributação e Políticas Públicas: O ICMS Ecológico". In TÔRRES, Heleno Taveira. Direito Tributário Ambiental. São Paulo: Malheiros, 2005.

TENÓRIO, Fernando G. Gestão Pública ou Gestão Social? Um Estudo de Caso, 2002. Disponível em: <http://unpan1.un.org/intradoc/groups/public/documents/CLAD/clad0044562.pdf>. acesso: 29 ago. 2009.

TUPIASSU, Lise Vieira da Costa. Tributação Ambiental: a Utilização de Instrumentos Econômicos e Fiscais na Implementação do Direito ao Meio Ambiente Saudável. Rio de Janeiro: Renovar, 2006.

VEIGA NETO, Fernando Cesar da. Análise de Incentivos Econômicos nas Políticas Públicas para o Meio Ambiente. O Caso do ICMS Ecológico em Minas Gerais. Dissertação (Mestrado em Desenvolvimento, Agricultura e Sociedade) - Curso de Pós-Graduação em Desenvolvimento, Agricultura e Sociedade do Instituto de Ciências Humanas e Sociais da Universidade Federal Rural do Rio De Janeiro - CPDA / UFRRJ, Rio de Janeiro. 2000. 